\title{
AN ANALYSIS SLANG LANGUAGE FOUND IN KELUARGA BESAR GROUP WHATSAPP
}

\author{
Yohanes D. P. L. Benany \\ Kanjuruhan University, Malang \\ dedemuliphaty14@gmail.com
}

\begin{abstract}
This study was conducted to examine the types of slang words and the meaning of slang language used by members of Keluarga Besar group WhatsApp. This research contains with morphology and phonology to find out types of slang in terms of phonology, Chrystal (1992) was employed to analyze the data. The researcher also used theory from Harimurti Kridaksana (1989) to analysis the Tetun slang language in terms of morphology. The researcher used the theory from crystal (1992) to analysis the data from $17^{\text {th }}$ until $17^{\text {th }}$ November 2019. It was found that from four types of slang languages in terms of phonology, there are three kinds of slang languages applied by the members of Keluarga Besar group WhatsApp. 115 times of occurrence was found in their conversations, divided into: addition (15), replacement (2), sound transposition divided as: word reversal (80), PVB (14), insert one letter (2), sound change (2). While for morphology process, it was found that from four types of slang words in terms of morphology, there are two kinds of slang language applied by the members of Keluarga Besar group WhatsApp. 13 times of occurrence was found in their conversations divided into: prefix (11), infix (1), and reduplication (2).
\end{abstract}

Keywords: slang language, WhatsApp, Keluarga Besar.

\section{INTRODUCTION}

Language is a communication tool used by human to conduct communication activities with others. Language is interpreted as an expression for others where something that is meant can be understood by the speaking partner. According to Chaer and Agustina in Rizky (2012), "the main function of language is as a communication tool". If talking about language we cannot separated it from social life because in social life language have function such as make a rule, explain the rule and also giving information. When one individual interaction with another one or they are makes interaction in one community its means they are have make social interaction. "Social interaction is the key to all social life because without social interaction there is no life together" Soedjono Soekanto (Pratiwi 2012).

Sociology is the study about the interaction in the society. According to Max Weber in Warsito (2016), sociology is the science that study focus on social action to explain the cause and effect of the phenomenon. From the statement can be understood that sociology cannot be separated from human life. One of branch in sociology is sociolinguistics.

"Sociolinguistics is a branch of linguistics science that is interdisciplinary with sociology and the object of research is the relationship between language and social factors in a society" (Chaer and Agustina 2010:2). In conclusion socio-social science in addition to studying the structure (phonology, morphology, and syntactic structure), sociolinguistic also 
examines heterogeneous languages. Factors that cause language heterogeneity are situation factors and the background of the speaker. This influence gives impact on language variants.

According to Chaer (2010:62) says that language variations differentiated by (a) the geographical and social background of the speaker, (b) the used of media and (c) subject matter. on variations in terms of speaker also divided into four types such as: (a) idiolect, (b) dialect, (c) chronolect, (d) sociolect. In sociolinguistic have two kinds level of language there are formal language and informal language. Formal language is the language that used by people in the formal situations for example conversations between manager and employers in the meeting, conversation between teacher and students in the classroom. While informal language is the language that used by people in the informal situation for example conversation between buyer and seller in the traditional market, conversations friends in coffee shop and etc. Actually, there are three kinds of informal language such as jargon, register, and slang.

Slang is a form of language that is special and confidential. "slang language specifically used by certain circles person who are very limited and confidential not everyone knows the meaning of that conversations carried out by members of the group"(Soeparno 2002:73). "Slang language also called prokem language, this is because the slang vocabulary is always changeable, temporal, and usually used by young groups" (Chaer and Agustina 2010:67).

In social life people do not always speak with common language but also local language. In East Nusa Tenggara there is one group who used original local language (Tetun local language), to make a new language (slang language) by reversed form the original language. Slang of the local language estimated appeared in 2000 and now have 30 members scatted around Bali island and other members in Alas Village.

In the modern area slang can be found in every social media this also applied by the members of Keluarga Besar of Tetun slang language. They always make interaction used slang language in social media in this case they make group in WhatsApp social media. In their conversation there are a lot of slang words uttered by the members of Keluarga Besar group WhatsApp.

Slang that uttered by the members of Keluarga Besar group WhatsApp has hidden the phonology and morphology process that need more research to be understood. To understand the process of formed the slang word in terms of phonology and morphology we need to know about how the slang word formed from the original local language.

The study of slang language has been analyzed by many researchers. In order to make this research to be better the researcher of this research uses some previous study that related to this subject. The first researcher that studied about slang language is Pradianti (2013) The use of slang words among junior high school students in everyday conversation the researcher found that slang is usually using by junior high school in their daily conversation in this research the researcher using quantitative method to collect the data and show how percent the student of junior high school using slang words in their conversation. 
Another researcher is (Rachmawaty, 2012) with the title Lawikan Kera Ngalam di Tengah Arus Globalisasi found that Walikan language or we know as slang language from Malang East Java is the language that born from the habits of the local community in communicating. There are many researcher that research about slang language such as (Hidayah, 2018) with the title "Pemetaan Bahasa Walikan Masyarakat Malang Di Kota Malang also from (Andrayani, 2016) entitled "Culture, Identity and Local Media.

After examining the findings of the previous study, it can be concluded that the previous study is only focused on researching the rules of Malang Walikan language and the Yogyakarta Walikan language. The rules that uses in the formations of the reverse languages. And it can be concluded also that there is an inequality between one research and other researcher regarding rules in inverse language. Slang language is a language that is only understood by a group of people, so if the language has been made a dictionary or already provided, the language is not a slang language because it is already known by people who are not in the that language community.

The reason why the researcher wants to make a research about the Tetun walikan language because there is no previous study research about this language especially the formed of this language in terms of phonology and morphology. Many previous studies just focus on the rule age of used the Walikan language and most researchers only focus on Yogyakarta Walikan language and Malang Walikan language. This research is expected to be able to help further researcher especially in slang or Walikan language.

Based on the problems that have been discussed, there are two problem of study can be formulated the first is what are of slang words formed in terms of phonology and morphology in Tetun local language, and the second is What are the meanings of the Tetun slang local language.

\section{METHOD}

Phonology is the branch of linguistics that study, analysis, and discussion about sound of the language (Chaer 1994: 102). Crystal in Amrullah, 2013:23) said that "slang is the game of sound and letter that formed from the process such as Addition is the way to makes slang word with adding the vowel in the beginnings of the original words. The second is compacting is the way to makes slang words with removal two or more letters in the original word and then make the new words or slang words. The third is replacement is the way to makes slang word with changes the form of the original words or takes another language to replace the real meaning of original word become new words or slang words.

According to Crystal (1992), another ways to make slang words is sound transposition there are reversal words is the way to make slang word with reversal the structure of the original word, Put vowel in the beginning of the word is the way to make slang word by putting the vowel letter in the beginning of the original words, insert one letter is the way to make slang words by insert one letter in the middle of the original word then the word become new word 
or slang word and sounds change is the process of make the slang language by changing the sound of original language become new word or become slang word.

According to Soeparno (2002:24) said that "morphology is sub-discipline linguistics that study about form, process, and word formation procedure". There are some ways to make a slang language proposed by Harimurti Kridalaksana(1989) the first is affixation According to Chaer (1994:117), "Affixation is the process of affixing the original word or morpheme". Affixation divided into three types as follow: prefix, suffix, and Infix. The second is reduplication or repetition is the process of repeating words or element of words. Reduplication is also a process of decreasing words or partial repetition. The third is Abbreviation is the process of decapitation part of a lexeme or combination of lexeme that is make the word become a short form but the meaning still same as the meaning in the complete form. The last is composition or compounding is a process that combines two basic morphemes into one word.

This study used descriptive qualitative. According to Cresswell (1994:145), "qualitative research is descriptive in that the researcher interested in process, meaning and understanding gained through word or picture" which mean the qualitative method is an analysis data which produce a natural data or original data. That statement related with this research, because in analyzed the data the researcher taken naturally without reducing, adding, or changing anything from the original data source. In this research, the researcher used participant in this case interview the expert of Tetun slang language to get the meaning and process of formed the slang words.

In this research data source is taken from the Keluarga besar group WhatsApp. While the data in this research taken from the conversations between ten members in the Keluarga Besar group WhatsApp. For the process of collecting the data the researcher open the Keluarga Besar group WhatsApp, read the conversation in Keluarga Besar group, sorting out words contain with slang language, Sort out words contain with slang language, screenshotting the conversation containing with slang words, Sending the screenshotting and interview the experts of slang word and the last is Sending the screenshotting and interview the experts of slang word and the last step is Providing the result of interview.

For procedure of data analysis the researcher classifying words and sentences containing Tetun slang language in terms of phonology based on crystal theory (1992), identifying the number of each type of Tetun slang language, getting the preliminary findings, Consulting the preliminary findings with validator, and the last is make Findings and conclusion. For the process of triangulation the researcher Re-reading conversations in Keluarga besar group WhatsApp that contains with slang words to get the better understanding after that Finding out and write in the book every words in sentences of Tetun slang language that uttered by the members of Keluarga besar group WhatsApp, and then Classifying and analyzing words or sentences containing with Tetun slang words.

\section{FINDINGS AND DISCUSSION}


This research attempts to describe the kinds of a slang word that found in conversations between a member in Keluarga Besar group WhatsApp and the finding section will be shown the result of the data analysis. The data in this research were taken from the conversation between members in Keluarga Besar group WhatsApp, from 17 September until 17 November 2019. The occurrence frequency of the formed of slang language is given in Table $\mathbf{1}$.

Table 1. Tetun slang language in terms of phonology

\begin{tabular}{lc}
\hline \multicolumn{1}{c}{ The Ways to Make Slang Words In Terms Of Phonology } & Frequency \\
\hline Addition & 15 \\
\hline Replacement & 2 \\
\hline Sound transposition & 80 \\
\hline Word reversal & 14 \\
\hline Put vowel at the beginning of the word & 2 \\
\hline Insert one letter & 2 \\
\hline Sounds change & 2 \\
\hline
\end{tabular}

Those slang words are found spread over the conversations in Keluarga Besar group WhatsApp in terms of phonology. The corpus used in this analysis helps to classify the data easier. after the data were found and classified as above, then the data are analyzed to interpret the ways to formed Tetun slang words in terms of phonology that the author want to emphasize and tell the readers.

Table 2. Tetun slang language in terms of morphology

\begin{tabular}{lc}
\hline \multicolumn{1}{c}{ The Ways to Make Slang Words In Terms Of Morphology } & Frequency \\
\hline Affixation & 11 \\
\hline Prefix & 1 \\
\hline Infix & 0 \\
\hline Suffix & 2 \\
\hline Reduplication & 0 \\
\hline Composition & 0 \\
\hline Abbreviation & 0 \\
\hline
\end{tabular}

The formed of Tetun slang language in terms of phonology and morphology is the first research question and in order to answer research question number 1, the researcher looking up for the definition of each type of the ways to formed slang words in terms of phonology and morphology as mentioned by Crystal (1992) and Harimurti Kridalaksana (1989) in the chapter two. This study analyses the ways to formed Tetun slang words in terms of phonology and morphology which are found on Keluarga Besar social media group WhatsApp. To make sure that findings are accurate the validation is needed. In this research the author used two persons to validate the data the first is the lecturer of English Literature Department and the second is the one member of Keluarga Besar group WhatsApp. 
After doing the analysis, many words and sentences of Tetun traditional language are containing with the slang words in terms of phonology and morphology. total are 115 data in terms of phonology consist of 8 types and 13 data in terms of morphology consist of 7 types of the ways to form the slang words that have been classification in the table above. The traditional word that contains with the ways to formed slang words in terms of phonology especially sound transposition as word reversal is “dida saso e ela vt,uha tu'a diko luse ph ene, san'o ala ono diko luse ph ene"(have you think to buy this television, I want to sell this television to pay may credit phone. I do not have money to pay this credit phone). The sentence is reversal word by word from the original traditional language "dadi sosa tv e lae, hau atu kodi selu hp ne'e, osan la no kodi selu hp ne'e. (CV-012 pages 28 ). After classifying author then see that in the process of formed the slang words the members of Keluarga Besar group WhatsApp reversal each word of the original traditional word becomes new word or slang words. The process of reversal the original traditional language become slang language will be explained further.

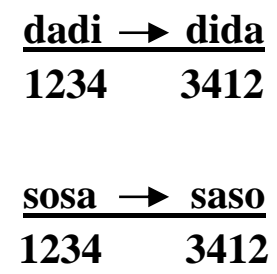

All the data were analyzed using the method. Since all the processes were conducted by the author himself, that is why Validator Triangulation is used to avoid the fault of the data analysis.

115 data are containing with the slang words in terms of phonology consist of 8 types were found in the conversations between the members of Keluarga Besar group WhatsApp. From those all types the ways to formed slang words in terms of phonology, sound transposition was the kinds that most used by the members of Keluarga Besar group WhatsApp.

Slang words that formed by sound transposition divided into 4 ways there are; word reversal occurs 80 times with $69.58 \%$ followed by put vowel at the beginning of the word (PVB) occurs 14 times with 12.18\%, insert one letter 2 times and also sound change 2 times with $1.73 \%$. The second one is the slang word that formed by used the ways of morphology, affixation especially prefix is the most ways that used by the members of Keluarga Besar group WhatsApp.

Slang words that formed by affixation divided into 3 ways there are; prefix occurs 11 times with $77.1 \%$ from total 13 data found followed by infix occurs 1 times with $7.60 \%$ and another ways to formed the slang words in terms of morphology is reduplication occurs 2 times with $15.30 \%$.

From the findings, it can be concluded that the dominant ways that used by the members of Keluarga Besar group WhatsApp is sound transposition in terms of phonology. While the ways formed the slang words in terms of morphology the members of Keluarga Besar group 
WhatsApp dominant used the kind of affixation especially prefix. From all the findings the researcher concluded that the most ways that used by the members of Keluarga Besar group WhatsApp in their interaction is reversal words.

The findings of this research and the previous research are not exactly same. The finding of Hermawan study found that slang from Yogyakarta it reserved in general. It usually uses habits or social agreements. Meanwhile in this study focus on slang language that Exist in East Nusa Tenggara. The differences between this research and the previous study are the object and the rule of making slang language, and the focus of research. In this research the researcher focus on kind of Tetun slang language while in previous study the researcher focus on how the language formed, age of the people who used the slang language and also about the phonetics, phonology, and phonotactics of the slang language.

In this research the researcher uses Tetun slang language used by the members of Keluarga Besar group WhatsApp as the data sources but in previous study the objective of the study is peoples or language from Javanese. In Keluarga Besar group WhatsApp. In Keluarga Besar group WhatsApp there are 10 members including the researcher himself. After conducting research, the researcher found that from the 10 members of the group only 4 people that often speak used Tetun slang language while, 6 members speak used an original language. The fourth member names are Felix, Yanti, Marin and Lia.

In the conversations of Keluarga Besar Group WhatsApp from $17^{\text {th }}$ September until $17^{\text {th }}$ November 2019, the researcher has found that Felix has been uttered 46 sentences of slang language, Yanti has been uttered 22 sentences, Marin has been uttered 21 sentences, and Lia has been uttered 24 sentences. Total sentence that is uttered by all members in the Keluarga Besar Group WhatsApp is 341 sentences. From 341 sentences, 113 sentences are classified into Tetun slang language. It is means, 228 sentences that spoken by the 6 members in the conversations of Keluarga Besar group used original Tetun language. From 113 sentences there are 115 words categorized into slang word.

\section{CONCLUSION}

The members of Keluarga Besar Group WhatsApp mostly make a conversation in terms of morphology used the kind of sound transposition especially reversal word. While in the terms of morphology, the members of Keluarga Besar group WhatsApp mostly used kind of affixation especially prefix. In the terms of phonology, they used reversal word because almost Tetun slang word was formed by reversal the original Tetun local language become Tetun slang language. While in terms of morphology, they used affixation especially sub kind of prefix because some words of Tetun slang language is classified into it.

The strategy that the members of Keluaraga Besar group WhatsApp used is based on the general function of slang word. Basically, the members of Keluarga Besar group WhatsApp used Tetun slang language to secret their communication with the other people who just understand the original Tetun local language. 


\section{REFERENCES}

Andrayani, K.(2016). Budaya, Identitas, Dan Media Lokal. Profetik: Jurnal Komunikasi, 8(2), 5-14. Retrieved from http://ejournal.uinsuka.ac.id/isoshum/profetik/article/view/1083

Hanifah, N. (2010). Penelitian Etnografi dan Penelitian Grounded Theory, 1-38.

Hermawan Nur Fadly. (2014). Basa Walikan "slang jawa," 2, 30-35

Kadarisman, N. Y. and A. E. (2017). On the Phonetics, Phonology, and Phonotactics of Basa Walikan Malangan Nurenzia Yannuar and A. Effendi Kadarisman Leiden University / Universitas Negeri Malang.

Pratiwi, P. H. (2012). Kehidupan Sosial Manusia. Pendidikan Sosiologi FIS UNY Dan MGMP, $1-15$.

Rizky, H. (2012). Bahasa Daerah Dalam Arus Globalisasi. Retrieved from http://eprints.uny.ac.id/9462/3/bab 2-08205244036.pdf 1-20

Rachmawaty, I. (2012). Lawikan Kera Ngalam di Tengah Arus Globalisasi, 1(1).

Rian, S. (2012). Penggunaan Register Pengundhuh Sarang Burung Lawet Di Goa Karang Bolong Kabupaten Kebumen, 6-21.

Sari, R. (2012). slang.1-114

Trimastuti, W. (2017). An Analysis Of Slang Words Used In Social Media Politeknik Piksi Ganesha Bandung, 5(2), 64-68.

Ulya, L. (2017). Bentuk dan Fungsi Ragam Bahasa Gaul Remaja Kota Metropolitan (Studi Kasus Pemakaian Ragam Bahasa Gaul Siswa SMA Negeri 66 Jakarta), 1-11.

Warsito, (2016). Bab. 1 Sosiologi Industri, 1-241. 